\title{
照明サロン
}

\section{2 力国見聞（その2）}

\section{ローマのあんちやん}

ローマの人の流れは東京そっくりだ，過剩人口で生活 も楽でないようだ，古都口ーマの歴史を語つている旧跡 は警異をもって見たし，有名な終着駅やオリンピック・ スタジアムなどは近代的美しさで構成された﨡力にあふ れたものである。しかし街全体の有様は筫そくさい，市

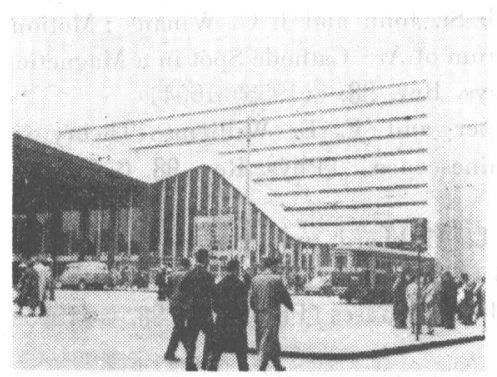

第11図ローマの終着駅

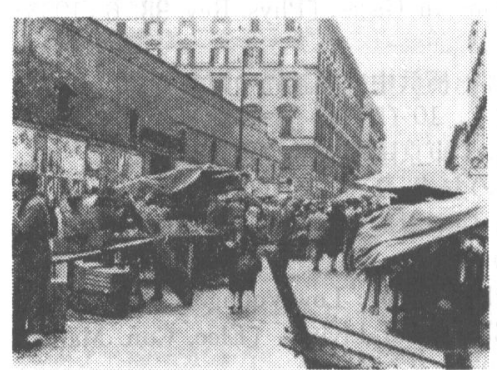

第12図口ーマの屋台店
街の中心に近 い所治生の食 料品の屋台店 がずらりと並 び，おかみさ ん連中が買出 しに歩いてい る.こ5い5 場所は臭くて きたない、繁 華街を歩いて いるとがらの 悪いあんちや んが「パーカ 一を買わない か」とらるさ くつけまわ す. 航空会社 の案内所の人 間は二流ホテルとタイアップしていてそこへ泊らされ た．このホテルで料金を弗で払扮拈としたら，ごまかそ らとした。指摘したらにやにやしながら返してくれた。 ローマは東京の終戦数年後の状況のよ5に感じた。

\section{チップをねだる役人}

ヨーロッパの旅を終光、エジプトのカイロへ行った。 晚方エジプトを空から見ると, どの街も明りが青白く， 諸所で見た空からの夜景と大分異っている，カイロに着 いて立派な水銀灯の街路照明が施されていることを知っ た。

カイロ空港の税関で、ヨーロッパで買った若干の土産 品をとやかくいうので, 洗面道具等見まわり品のみを持

* 日昭電気株式会社

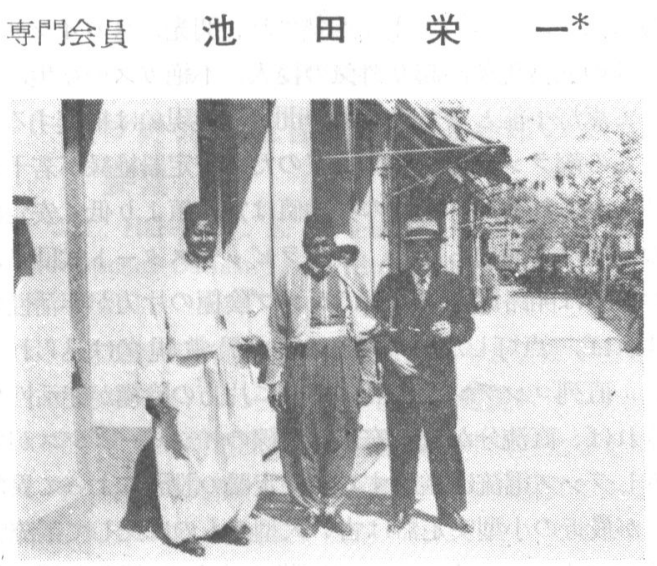

第13図力イロのホテル・セミラミスのボーイと ドアマン

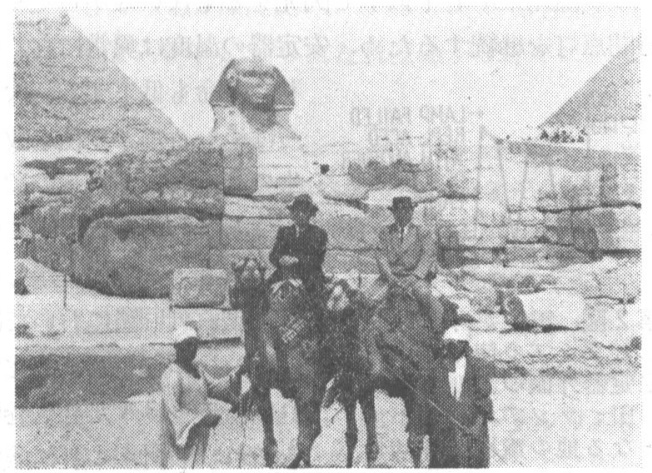

第14図 スフインクスとピラミッド

って，他の荷物全部を税関に預けて来た，ところが出国 のときの空港が前のと同じでなかったので，税関の役人 が先方へ電話して, 出発間際にやっと荷物が取寄せられ た. 税関の役人が「タクシ一代を払へ」というので，そ れを渡すと，その男为他の役人を指さして「彼が面倒を 見てくれたのだから，エジプトの金があったら彼にやる のだから出せ」というので，若干渡すとそれを自分の引 出しに入れてしまった、今度はまた彼なる男が出してき て，前の男を指さして「彼が面倒を見たからよこせ」と いってまたとられた，それがすむとポータ等が出て来て また要求である，出発ぎりぎりにうるさくつきまとわれ るので, 残ったエシフプ貨を渡すと「わいわい」その金 の取りっこである

バスで航空会社のターミナルビルに着いたときは,「木 テルの者だと称する小僧が現われ，「ホテルはすぐそこ! 
だといって，荷物をからいでどんどん行くので後につい た，行けども行けどもホテルに着かず，途中で荷物を置 いて2弗よこせという。ややを得ずホテル洋いてから 払らことにして，やっとホテルの立関に来たら彼はホテ ルの人間ではなかった，街の靴磨は靴に何かぶっかけて 污れているから磨かせるという，磨き上がると決めた值 段よい高いものを要求する. 油断もすきもならない.

カイロは発展しつつあることる事実である。モダーン カイロに大ビルが林立し，新式のビルも幾つか建築中で ある.十七几大統領といら新指導者のもとに伸ぴ上ろう としていることも確であろう。しかし指導者と一般国民 との間の隔りが余りに大きすぎる。

\section{ベイルート}

レバノンの首都ベイルートは聖書によく出てくるレバ ノン山を背にした近代都市である。東地中海第一の自由 貿易港で, 交通の要衝でもあり, 観光地でもあって, 旅 行者の多く立寄る所である，近代的ビルが立並び，自動 車も多く、ヨーロッパ的ふんい気の街で, 活気もあり, 新しい小独市国だが割合に栄えているよらだ。

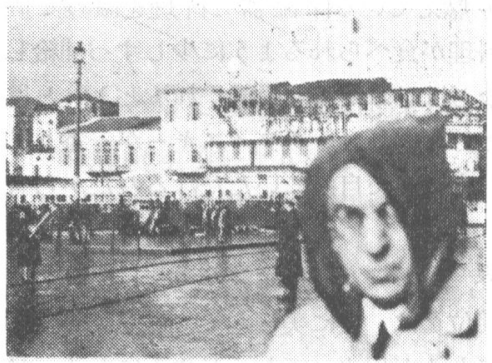

第 75 図ベイルート

自動車のサ イレンや電車 のチンチンガ やかましい， 人間は5すぎ たない.カイ 口程ではない が，荷物を持 連ぼらとする 浮浪者や，や か交しく寄って来て物を善付けようとする者なども多 く，大体低級である。レバノンは中東には珍しく緑の濃 い国である.

\section{0 度の酷暑}

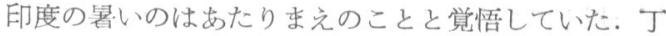
度5月初旬であったが, この地の真夏の由。デリの温度 は 110 度 $\mathrm{F}$, 空気は乾操しているが，110度とい5温度 は何んといって子暑い，森羅万象の内人間の身体がいち ばん冷たいようなものだから，やりきれたものではな い、こんな暑さでは人間の頭もさえる筈はなく，充分な 活動ができる䈂もある屯い。

ニュー・デリの官庁街は堂々たるものである. 政府は 大財閥をバックにしている由. 最大の財閥ビルラ個人で 建てた大理石造の大封完の現模の茌大さは驚くばかりで ある、大篍は裸か，粗末な死をまとった程度で，炎熱で

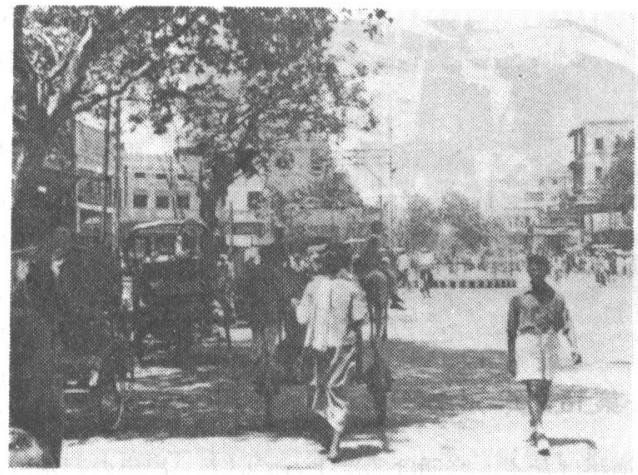

第16図オールド・デリの繁華街

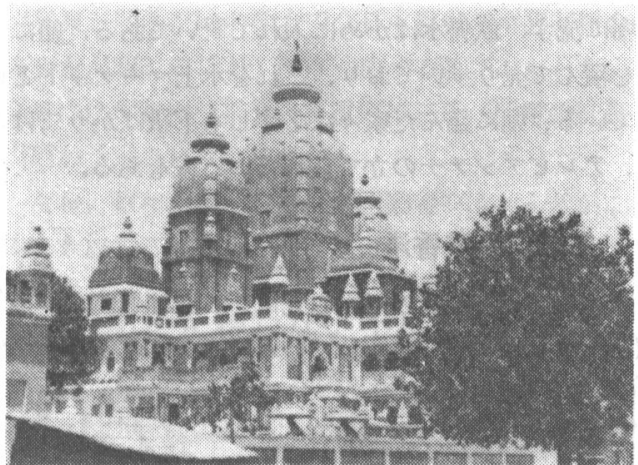

第 17 図] ニューデリ・の財閥ビルラ個人で建てた 大理石造寺院

筧けたアスフアルト道を裸足で歩いている。下剭階級は 日本円にして 1 日 8 円程度で生活して捄り, 平均寿俞は 38才とのこと、牛様は人間より尊敬され，街路をゆう中 5 と御散歩の牛椂に, 自動車も人間も道を战ゆずりしな ければならない。

ネールがアメリカとソビエットとの間でうまく立龱 り，東亜に捣ける最高の指導国家だと威張っているそう だが，扣こがましい次第だと思う。

カルカッタはデリより温度は低いが, 湿度が高く、丁 度日本の真夏の感じだ。洋式の堂々たる建築も相当多い が, 概して活らしく, 街はやかましい。

\section{水の生活}

タイ国バンコックの街は概してきたない，道路は立派 に舗装されているが，活溝がむき出しになっている，日 本に似た木造建築が多い，日本人そつくりの顔立の人が 相当いる，5つかり日本語で話しかけたら手をらられ た，電気工事の乱雑さには，上くこれで火事が起らない のかと驚かされた。街の電気屋には日本 司ママーク入 りの配線器:具が売られているが，きわめてお粗末なるの で，聞いたことのないようなメーカ名が記人されてあ る. 


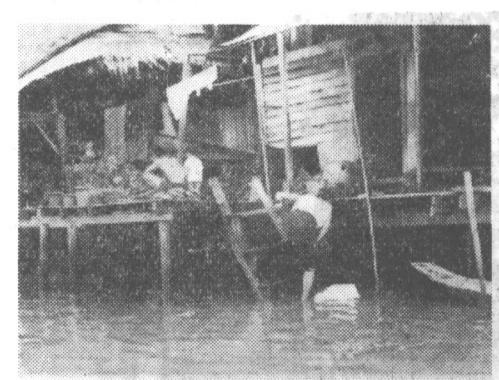

第 18 図 ベンコックの水の生活
メナム河の 周辺に堀割り がある.堀の 两側は商店や 住宅で, 家の 前側は堀に突 き出ており， 電柱子堀の中 に立ってい る. 家の背後 に道路はなく，交通は船によっている，褐色の泥水で身 体子洗い，顔や髟子洗っている．洗濯子する. 污物はこ の堀に流寸. 飲料水はかめに入れて置いてある. 船に商 品を積んで売り歩いており，これを水上マーヶットとい っている，堀に臨んだ家々は必ずしも下級ばかりではな く, テレビアンテナの立てられている家もある.

\section{自由貿易港香港}

国際都市查港とその対岸の九童，ここはさすがに活気 横溢，街もされいで整頓している.店々には世界各国の

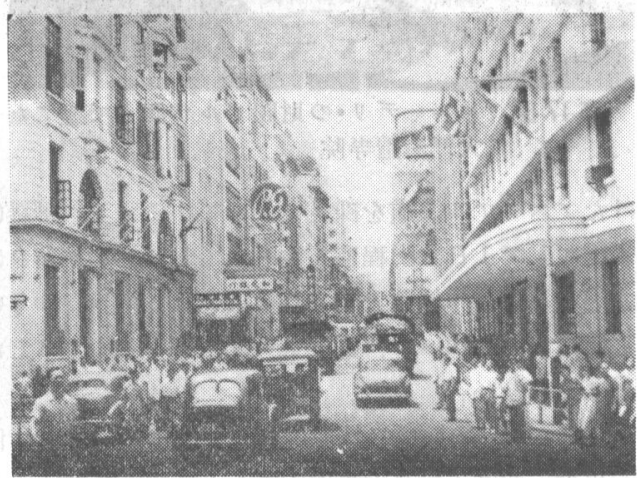

第 19 図 香 港 市 街

商品が山のように並べられ，それぞれの品の生産国より 值が安い。時計などスイスで買う同じ品物がここの方が 安洒である。

香港は世界有数の泉い都市だと思う。ただ水が不自由 なのが点だ。九竜の一流ホテル・ミラマで，風吕に入
れる時間が夕方与時から8時となって扣り，給水は時間 制で，朝の洗面用水は前日の汶置きを使わされた。

\section{日本よいとこ}

こうして外国を硯いてみると，日本はよいとこだと思 5 .

食物は, 日本食, 洋食, 中華食と榃界各国の料理があ り，それぞれ皆上等なるのがある。しかも西洋料理が日 本が一番らまいのだから嬉しくなる。アメリカの食物な ぞは大体一様な規格品で,一流の料理店で食べても，田 舎の場末のカフェテリヤで食べても味はあまり変らな い.ひどくまづくて食べられないというものもないが, あれを食べに行きたいと食欲をそそるような料理も見当 らない，概してぱさぱさしている。その他の各国でる大 同小異で，食物を楽しんだといら経験は余りなかった。

しかしフランスはさすがに酒落もたのがある。かたつ むりなども一寸いける、ヨーロッパのパンは皮がとても かたく，これをむしってバターもつけづに食べている. このパンなどはよく味はって見るとうまいと思う。ヨー ロッパの一流の料理店では，テーブルのそばに打灯明の ような小さい火が然えている保温器で料理を温めて置 き，終る迄温い料理が食ぺられるように少しすづ補給し てく机る。これなどは日本でも真似てくれるとよいと思 5、酒は筆者にとってはスコッチウイスキーが一番らま いと思うが,これも日本で自由にいただけるのたかから有 難い.

日本女性は世界一だとい5のは定評の通り。白人女性 は高等学校の生徒位迄は, 実に美しくて, 可愛いが, 20 才位になると顔にしみが出来，毛むくじやらになる。日 本女性のような中年つ魅力などは見られない，真の女性 美は宋洋にあるようだ。

スポーッや兴楽など，世界のどこかでやっているもの で, 日本で見られないというものはほとんどない。

日本は世界の多くの国々に比べて，誠によい国であ る。しかし, 道路の悪さ, 街並の不整然さは, 中近東の 国々以上である、日本の都市のよ5に街中くもの巣のよ らに架線が張りまわされている都市は見られなかった。 